\title{
Outside the University: (Re-)Constructing Self and Other in Marina Lewycka's „A Short History of Tractors in Ukrainian"
}

\author{
Oksana Blashkiv* \\ Siedlce University of Natural Sciences and Humanities \\ 2 Konarskiego Str., Siedlce 08-110, Poland
}

Received 04.03.2015, received in revised form 05.05.2015, accepted 21.05.2015

Although Marina Lewycka's novel „A Short History of Tractors in Ukrainian” is traditionally mentioned in the context of immigrant literature, it might prove to be more interesting if viewed from the perspective of the academic novel. A satirical image of a desperate thirty-six years old Ukrainian woman Valentina ready to marry a widower in his eighties for the sake of naturalization in the UK often overshadows the image of the British university teacher and this man's younger daughter Nadezhda, who goes through a tough process of identity (re-)construction while trying to protect her father from the second marriage. Being born, raised, and educated in the UK, being a UK citizen with an active social position, Nadezhda not only holds British values dear, perceives herself as British (in fact born into the family of Ukrainian immigrants), but also as a university professor passes them on to the following generations successfully until the actual "invasion" of the Other into her life takes place. The (re-)construction of Nadezhda-the-daughter identity together with the image of the Other is a tough process consciously monitored by a satirized Nadezhda- the-university-professor. The role of the university and education in general proves to be decisive in this process, uncovering the conflicting multiple identities.

Keywords: academic novel (Professorroman), immigrant literature, university, identity, the other.

DOI: 10.17516/1997-1370-2015-8-7-1511-1519

Research area: philology.

\section{Introduction}

„A Short History of Tractors in Ukrainian” by Marina Lewycka was published in 2005 and awarded the Bollinger Everyman Wodehouse Prize, which is the only literary award for comic literature in the UK, and the Saga Award for Wit; it was also shortlisted for the 2005 Orange Prize for Fiction. The novel has been translated into many languages and received universal acclaim as a satirical book, but not in Ukraine: there was no translation into Ukrainian until 2013, nor was there a particular interest on the part of Ukrainian literary critics, probably due to a rather stereotypical image of Ukrainians circulating within Western culture nowadays. Viewed from the distance of ten years, though, the novel serves as literary evidence of social and

(C) Siberian Federal University. All rights reserved

* Corresponding author E-mail address: nkovtun@mail.ru 
cultural changes taking place in Europe since the dissolution of the Soviet Union.

Recently the novel started to be mentioned within a new trend, i.e. immigration literature and all the complex questions connected with globalization, multiculturalism, and identity issues. In "Facing the East in the West: Images of Eastern Europe in British Literature" (2010) the novel is mentioned in a broad context of East European images as presented in the British literature over the last decades (Korte, 2010). Lechner (2010) focuses on the novels' popularity building on the concept of "transcultural capital", placing Tractors in line with White Teeth by Zadie Smith (2000) and Everything is Illuminated by Jonathan Safran Foer (2002) and stressing the novels' balancing between humorous depiction of immigrants and the latterly traumatic experiences of WW II. Turkich scholars Töngür and Çevik (2013) interpret the correlation between two cultural phenomena in Tractors, i.e. the Ukrainian immigration into the UK and the consumer society. Monika Manolachi (2014) analyzes the theme of female immigration as reflected in the novel from the perspective of gender studies. The dialogue between the past and present in Tractors was analyzed by Guilia Da Lia (2012) and Natalia Volkovets'ka (2012) contrasting Lewycka's novel with Kapka Kassabova's Reconnaissance and Oksana Zabuzhko's The Museum of the Lost Secrets respectively. Despite a variety of perspectives, the issue of English/British identity has not been addresses by the critics so far, while this approach seems to be especially productive due to the fusion of the literary genres within Tractors, i.e. the family novel and academic novel.

Contemporary studies on the 'academic novel' show a variety of definitions and genre distinctions (Womack 2005, Moseley 2007, Głowala 2010, Williams 2012). Williams proposes "to distinguish among the novels that center on students and those that center on professors", calling the former the "campus novels" and calling the latter the "academic novels", i.e. featuring academics at workplaces, at home and in marriage, "although the action is rarely confined to a campus" (The Rise, 561-562), but predominantly in a satirical context (Womak; Showalter). This kind of subgenre is also called Professorroman as coined by Richard G. Caram and fixed by Elaine Showalter. Traditional for the academic novel is a depiction of the university as an ivory tower: "The university is a closed world, with its own norms and values, which is thick with the possibilities of intrigue." (Showalter, p. 3) Janice Rossen believes academic novel is mostly about power, inclusion, and exclusion, and the academics in them reinforce the idea of "comprising circles which are closed to the uninitiated" as well as tend to compete with each other for the position of power. The female professor appearing in the university and in the academic novel in the 1970s brings a whole new set of expectations and stereotypes ascribed to her as a woman in academia. The image of the university professor Lewycka creates is another caricature which pictures a female university professor of sociology who is placed outside the university and is incapable of 'applying' theory to the actual case study, nonetheless balanced by her unexpected and involuntary search for identity.

According to Ian Baucom, the struggles over defining, reforming, defending Englishness go down to the struggles to control, possess, order and dis-order the nation's and empire's space (Out of Place, p. 4). The British literature of the last decades addresses this problem excessively, which nonetheless leaves the question of Englishness open (Kolenda 2013). The issue of English identity has been investigated by Olga Bandrovs'ka (2009) on the basis of D. Lodges's Changing Places and A. Hollinghurst's The Line of Beauty: in conclusion the author states that 
the globalization tendencies at the turn of the 21 century influence the historically determined English character changing it in the direction of liberal worldview and the loss of national characteristics. The social constructivist research on identity show that the idea of the existence of absolute self is rejected and "instead regard identities are constructed, co-constructed, confirmed and negotiated by individuals in and through discourse at a particular point in time and place" (Goncalves 2013). However, not always can the possibilities for identity construction be negotiated: there can also be "imposed" and "assumed" types of identity, in addition to "negotiated" ones. Lewycka's novel proposes a wide range of possibilities for the interpretation of identity issues among which I will focus on the narrator's assumed (English) and negotiated (Ukrainian) constructs.

\section{Identity Quest}

The plot of Tractors is simple: a Ukrainian divorcee Valentina, aged 36, together with her son Stanislav comes to the UK to marry Nikolai, a Ukrainian man in his 80 s. This event unites his daughters with the symbolic names Vera (aged 57, born during war-time in Ukraine) and Nadezhda (aged 47, "a peacetime child" born in Britain) in their efforts to get rid of the family intruder. The 'battle' takes place in late 1990s in Peterborough, Cambridgeshire, where lives a small community of émigré Ukrainians, who settled there after WW II. The story is told by Nadezhda, one of Nikolai's daughter, who also happens to be a university lecturer at Cambridge, but not at Cambridge University - she teaches sociology at Anglia Polytechnic University. She is a bearer of a liberal worldview, has liberal opinions on immigration, she is a feminist, she is well-informed about the contemporary state of things in Europe and considers herself to be British, tolerant and well-educated. Everything changes when an aggressive intruder Valentina comes into the family and crashes the British mirror into pieces, making Nadezhda fall onto the level of an 'ordinary' intolerant and filled with stereotypes advocate of British imperial thinking and a defender of the British Isles against the East European post-communist golddiggers and, what is more important, making her remember her own immigrant background, of which she seems unaware until the moment the Other "explodes" into her life "like a fluffy pink grenade, churning up the murky water, bringing to the surface a sludge of sloughed-off memories, giving the family ghosts a kick up the backside" (Tractors, p. 1).

For Nadezhda the Other is embodied both in Valentina who poses an actual threat to her family marrying her father and the unknown (or not fully known) story of her family's Ukrainian past. Although Valentina is the aggressive Other, she is not a real enemy to Nadezhda, but she is a 'bad' mirror of Nadezhda herself or a 'good' reason to face the real enemy, which is the sloughed-off memories and the family ghosts. To get rid of Valentina, she collides with her sister Vera with whom Nadezhda has not been on speaking terms for two years, but at the same time she fights her sister, who she feels closely connected to her Ukrainian-ness as "the guardian of the family archive, the spinner of stories, the custodian of the narrative that defines who we are" (Tractors, p.49) and possibly even tries to fight a family trauma she knows nothing of: "I have a sense of something terrible that has happened in the past, which no one will tell me about because even though I am in my forties I am still the baby: too young to understand" (Tractors, p. 45).

Vera is ten years older, born in Ukraine, with her parents she survived the war and the Correction Block in the German labour camp, and came to the UK never to talk about the past, but to work hard, keep the head down, learn the 
language and integrate (Tractors, p. 240). The starting point for both sisters was absolutely different which made them people of two different worlds and worldviews: "There were ten years between Vera and me - ten years that gave me the Beatles, the demonstrations against Vietnam War, the student uprising of 1968, and the birth of feminism, which taught me to see all women as sisters - all women except my sister, that is" (Tractors, p. 239).

The "Other" becomes an enemy only when we are unsure in our own identity, we can say that Nadezhda is trying to find out who she is. She was aware of her Ukrainian-English identity when her mother was alive, but with her death Nadezhda cut off this part of herself together with her sister which seems to be over the disagreement about their mother's will, but in fact because Vera had taken up the position of the "family archive" keeper. Her father, on the other hand, is not associated for Nadezhda with Ukrainian identity, but rather English: "He always speaks to me in English, eccentrically accented and articled, but functional. Engineer's English. My mother spoke to me in Ukrainian, with its infinite gradations of tender diminutives. Mother tongue" (Tractors, p. 15). The English language and its intonation help Nadezhda to keep distance from "all the pain and madness", in other words - from her enemy. English also gives her a chance to bring a whole set of British values and cultural tradition to the level of conscious analysis to explain the situation to herself, instead of going with emotions. But at some point the situation with her father's marriage aggravates and the emotions take hold of her and she turns from a "university lecturer" into Mrs. Daily Mail (Tractors, p. 82) and Mrs. Flog-'em-and-send-'em-home (Tractors, p. 161), using all the possibilities of the British legal system to save her father literally, and to save her British-ness metaphorically.
The language issue in the novel has been addressed by critics in various ways: as a means of achieving a comic effect - "the novel's humor stems from Lewycka's rendering of a snappy 'mongrel language, half English half Ukrainian' (p. 98)" (Lechner 2010: 442), as a indicator of the stage of immigrant assimilation in Britain, "as a powerful tool of linguistic [and cultural] differences" (Manolachi 2013: 257). I would stress the narrator's attitude to her mother tongue in terms of her identity: for quite some time she cannot bring herself to reading her father's poems to Valentina and notes on the history of tractors in Ukrainian, later she helps him with his English translation (what she does for the sake of her daughter who "adores her grandpa" rather, than his sake). Her fluent Ukrainian becomes obvious for the first time during the first major fight with Valentina, when even the English attitude of reservation and coldness cannot hold against the indignation stirred by Valentina's treatment of her father. It seems like at this moment she breaks through her Englishness and acknowledges a Ukrainian component of her identity. By the end of Valentina's stay in England Nadezhda fully performs the function of an interpreter during "family" gatherings, thus accepting her bilingualism.

Nadezhda's Ukrainianness is closely linked with the image of a Ukrainian woman deeply rooted in a traditional Ukrainian culture conflicted by the feministic perspective typical for the British society and the university. Nadezhda and her relations with her father and sister are shown through the lens of her feministic position adopted and accepted by Nadezhda in her youth which simultaneously distanced her from her Ukrainian family, where the role of a woman is defined through the symbol of Berehynia (the hearth mother and the protectoress of the home), which her mother fully represented. Her feminism is not supported neither by her father 
(the father talks more eagerly with her husband Mike, who is a man and must be treated with respect (Tractors, p. 37)) nor her sister (who considers it rather the result of her occupation as a social worker - a 'professor of sociology' and a 'social worker' make no difference to her and her hippie outlook). Nonetheless, when it comes to borrowing money, the father comes to his independent younger daughter first. She also becomes an authority on the rights of wives for her father when Valentina is instructed by her friends to demand the money for her car from Nikolai (Tractors, p. 86).

Nadezhda's profession interferes with the enforced role of her father's protectoress, when she tries to rationalize Valentina's behavior, manners, and style of clothing taking the university knowledge as a key to understanding: "But Vera, you can't judge someone by how they dress. ... I had a Ukrainian sociology professor visiting last year and she looked exactly like that. And she was upset that most of my friends wore no make-up and went around in jeans or tracksuit bottoms, when she yearned for designer clothes. She said it was a betrayal of womanliness" (Tractors, p. 83). Nonetheless, the professional approach does not hold against the reality and Nadezhda self-reflects: "And how am I enjoying my bitch-fest! What has happened to me? I used to be a feminist. Now I see to be turning into Mrs Daily Mail" (Tractors, p. 83).

At the level of narration though, the text continues to reflect a balanced row of observations done by an academic rather, than an attempt to create a special kind of écriture féminine. Nonetheless, the whole narrative is fragmented into the story of the present, the stories of the past told by Vera and the story of the father laid out in his book on the history of tractors; the narratives tightly intertwine from time to time producing the feeling of chaos in the narrator's mind, though meaning to bring back academic order and understanding. This 'scientific' approach to analyze the situation at the same time becomes a case of writing 'her own story' in the spirit of feminine writing and reconstructing her own identity:

"I sit on the bench under the wild cherry tree in the cemetery and sort through my memories, but the harder I try to remember, the more I get confused about which are memories and which are stories. When I was little, my mother used to tell me family stories - but only the ones that had a happy ending. My sister also told me stories: her stories were strongly formulaic, with goodies (Mother, Cossacks) and baddies (Father, communists). Vera's stories always had a beginning, a middle, and end, and a moral. Sometimes my father told me stories too, but his stories were complicated in structure, ambiguous in meaning and unsatisfactory in outcome, with lengthy digressions and packed with obscure facts. I preferred my mother's and my sister's tales. I too have a story to tell" (Tractors, p. 47-48).

Going through the history of her family Nadezhda is constructing her Ukrainian identity anew, yet this would not have been possible had she not been a well-educated British university lecturer. Her academic approach allows her to bring together "family stories" and history books to better understand herself. The historical digressions are not at all deprived of historical acuteness creating a distance between her personal attitude and British Ukrainian community's discourse on the topic. Among such topics are the Famine of the 1933-37s (Holodomor), the history of Ukraine since 1918, the events of WW II, and after-war immigration. The presentation of these fragments is rather instructional and detailed 
in terms of names and dates, producing an impression of an academic text, thus contrasting with the personal/family narratives (memories) given by Vera.

\section{University and Family History}

The study of the family history reveals interesting facts about the role education played in the family of Ocheretkos (mother's side) and the Majevskyjs (father's side). The Majevskyjs were teachers, Grandpa Majevskyj was Minister of Education for six months during the times of "Free Ukraine" in 1918, and later after Stalin came to power he was the head teacher of the Ukrainian language school in Kiev (Tractors, p. 62, 68) Nadezhda's mother Ludmila Ocheretko was a university student of veterinary until she was expelled for her father's political views (Ukrainian Nationalist). Ludmila's mother also worked as a teacher and she did not particularly like the Majevskyjs, representatives of the "small Ukrainian intelligentsia". Thus, the grandparents on both sides were well-educated people for their time and so were their children, i.e. Ludmila, a lecturer at the veterinary college in Kiev and Nikolai, who studied engineering at Aeronautical Institute in Kiev. Though not being able to professionally realize themselves in England, they passed the value of education to their children, one on whom - Nadezhda - made "a fabulous career" of a university lecturer. The same Nikolai wanted for Valentina's son: "It was for him! All was for him! Because she says he is genius and must have OxfordCambridge education!", exclaims Nikolai at the divorce hearing (Tractors, p. 286).

The traditional belief of the post-war Ukrainian emigrants in hard work and education as the road to survival and security in a new country, which was passed to Vera and Nadezhda from their parents and according to which they lived, clashes with Valentina's, the post-Soviet emigrant, from the start. She advocates the idea of the English-private-school education, and in order to provide her son with it she is ready to marry an 86-years old man who supposedly can pay for it. Nadezhda, on the other hand, climbed the ladder by herself and does not approve this shortcut:

"My father has not only rescued this beautiful Ukrainian woman, but he is also in a position to foster the talents of her extraordinarily gifted son. Stanislav, who is fourteen, has been to see an independent psychologist, who, for a modest fee, paid by my father, has tested his IQ, and written a certificate declaring him to be a genius. On the basis of this, the boy (also a very talented musician, by the way, plays piano) has been offered a place at a prestigious private school in Peterborough (of course he is much too intelligent for the local comprehensive, which is only fit for the sons and daughters of farm laborers.) My sister, who paid good money to send her extraordinarily gifted daughters to a posh school, is outraged. I, who sent my own extraordinarily gifted daughter to the local comprehensive, am outraged too. Our rage bubbles merrily up and down the telephone lines. We have something in common" (Tractors, p. 61).

Although Valentina does not know how the English system of education works, she understands its importance and for the sake of better prospects for Stanislav is ready to seek help even among 'enemies', she addresses Nadezhda at Christmas table: "I want for help Stanislav in OxfordCambridge University. You help?" (Tractors, p. 113). No matter how different the two women are, one thing they have in common - the understanding of the value of education and its importance in their children's lives. This is when 
Nadezhda accepts Valentina as a woman fighting for her child's future, so much resembling her mother. Valentina's story also helps Nadezhda to learn her own family story and to situate herself in the family history as a Peacetime Baby, barer of both narratives Ukrainian and English.

\section{Concluding Remarks}

Lewycka's novel though not being associated primarily with the academic novel, proves to be a good source to address the issue of Englishness and the image of the Other through the auto-image of the English university lecturer. At the beginning of the novel, the narrator's "assumed" English identity gets shattered into pieces to be finally "re-negotiated" as Ukrainian-English identity. The negotiation goes through re-establishment of the connections with the past, gathering the fragments of the family story as well as her fragmented identity: Nadezhda-the-adult (trying to keep distance and remain reasonable in given situation and support her father), Nadezhda-thedaughter (grieving the loss of her mother at the same time and being outraged at her father's marriage plans), Nadezhda-the-child (who she feels not in the company of her father, but her elder sister, who also is the one "who knows the family story" Nadezhda is "too young to be told and to understand"), Nadezhda-the-mother (fighting with her sister over their mother's will and codicil in favour of the granddaughters), Nadezhdathe-wife (trying to involve her husband into her father's case, but not making it an issue between them both), Nadezhda-the-Ukrainian (which she is either not aware of yet, or unconsciously suppresses and rejects), Nadezhda-the-English (which is her unquestionable state of mind),
Nadezhda-the-lecturer, who constantly analyzes the situation from different perspectives of her split identity and doing it absolutely consciously. This is that conscious inner voice aware of the multiple "I"s that makes it interesting to follow her story at the same time smiling at the satirical image of the lecturer outside the university.

Although the image of the university or the university life is not explicitly portrayed in the novel, the fact that the narrator is a university lecturer at a polytechnic university is in itself insightful. The polytechnic university was created in a postwar England to provide more technical education than was available at the time, hence reinforcing the instrumental (utilitarian) approach to education. The narrator lectures (not teaches!) sociology which should teach understanding society through people's behavior, which again stresses an instrumental approach to education. However, despite the intended practical approach to life the university supposedly provides you with, the real life offers many unexpected situations, which a person has to deal with alone as the theories do not apply; thus, contemporary instrumentalism lacks the general understanding of the world in all its complexity (cf. Crisis of Literaturecentrism, 5-7). In Tractors Lewycka has also indicated a contemporary tendency observed within the academic novel, i.e. the struggle of the academic novel with its own template - a story about a professor living his life inside the university walls - instead reaching beyond Professorroman and a satirical novel while picturing professors filled with all the anxieties typical of today's life within the globalized world outside the university. 


\section{References}

1. Baucom Ian. (1999). Out of Place: Englishness, Empire and the Locations of Identity. Princeton, New Jersey: Princeton University Press.

2. Beller M., and Leerssen J. (eds.) (2007). Imagology: the Cultural Construction and Literary Representation of National Characters: A Critical Survey. Amstredam: Rodopi.

3. Giulia Da Lio. (2012). Against Assimilatory Forgetting: Memory as Identity in Contemporary Fiction on Migration from Eastern Europe. Web File. <http://euroacademia.eu/presentation/againstassimilatory-forgetting-memory-as-identity-in-contemporary-fiction-on-migration-from-easterneurope/>

4. Głowala Z. (2010). University or Universal? Revaluating the Academic Novel. Lublin Studies in Modern Language and Literature 34, 20-34.

5. Gonçalves Kellie. (2013). Conversations of Intercultural Couples. Berlin: Akademie Verlag.

6. Kolenda Karolina. (2013). Angielskość i postpastoralizm. Rekonstrukcje i dekonstrukcje tożsamości we wspótczesnej powieści brytyjskiej. In: Bleinert M. (ed.) Dziewięć odston literatury brytyjskiej: Wiek XX po współczesność. Kraków: Wydawnictwo Uniwersytetu Jagiellońskiego 2013, 25-37.

7. Korte Barbara. (2010). Facing the East of Europe in its Western Isles: Charting Backgrounds, Questions and Perspectives. In: Barbara Korte, Eva Ulrike Pirker and Sissy Helff (eds.) Facing the East in the West: Images of Eastern Europe in British Literature, Film and Culture. IFAVL. Amsterdam and New York: Rodopi Press, 1-24.

8. Kovtun N. (ed.) (2014). Krisis literaturotsentrizma: utrata identichnosti vs. novye vozmozhnosti [Crisis of Literocentrism: the Loss of Identity vs. New Opportunities]. Monograph. Moscow: FlintaNauka. 576 p.

9. Lechner Doris. (2010). East European Memories? The Novels of Marina Lewycka. In: Facing the East in the West: Images of Eastern Europe in British Literature, Film and Culture, ed. Barbara Korte, Eva Ulrike Pirker and Sissy Helff. IFAVL. Amsterdam and New York: Rodopi Press, 437-450.

10. Lewycka Marina. (2005). A Short History of Tractors in Ukrainian. Penguin Books.

11. Manolachi M. (2013). Cultural Tractors and Gender Roles In "A Short History of Tractors in Ukrainian” by Marina Lewycka. In: Maria-Sabina Draga Alexandru, Mădălina Nicolaescu, Helen Smith (eds.). Between History and Personal Narrative: East-European Women's Stories of Migration in the New Millennium. Graz: Lit Verlag (Contributions to Transnational Feminism Series), 255-270.

12. Moseley M. (ed.) (2007). The Academic Novel: New and Classic Essays. Chester Academic Press.

13. Showalter E. (2005). Faculty Towers. The Academic Novel and Its Discontents. Philadelphia: University of Pennsylvania Press.

14. Töngür A.N. and Çevik J. (2013). Migration to a Consumer Society: "A Short History of Tractors in Ukrainian” by Marina Lewycka, "The Journal of International Social Research", Vol. 6, Issue 28, 441-450.

15. Williams Jeffrey J. (2012). The Rise of the Academic Novel. “American Literary History”, Vol. 24, No 3, Fall 2012, 561-589.

16. Womack K. (2005). Academic Satire: The Campus Novel in Context. In: Shaffer Brian W. (ed.). A Companion to the British and Irish Novel 1945-2000. Blackwell Publishing 2005, 326-339. 
17. Бандровська Ольга. Імагологічний аспект сучасного англійськаго роману. „Питання літературознавства”, Вип. 77, Чернівці 2009, 54-62. PDF File. Web. 5 March 2015. <http://dspace. nbuv.gov.ua/handle/123456789/18426>

18. Волковецька Н. (2012). Діалог минулого і сучасного у романах Оксани Забужко «Музей покинутих секретів» та Марини Левицької «Коротка історія тракторів по-украӥнськи». "Наукові записки Національного університету «Острозька академія»", Сер.: Філологічна. Острог 2012, Вип. 27, 133-135.

\title{
За стенами университета: (ре-)конструкция идентичности \\ в романе М. Левицкой «Краткая история тракторов по-украински»
}

Oksana Blashkiv Естественно-гуманитарный университет Польша, 08-110, Седльие, ул. Конарского 2

\begin{abstract}
Несмотря на то что роман Марины Левицкой «Краткая история тракторов по-украински» традииионно упоминается в контексте иммигрантской литературы, более интересным представляется его рассмотрение с точки зрения академического романа. Сатирический образ отчаянной тридиатишестилетней украинки Валентины, готовой выйти замуж за престарелого вдовия, чтобы получить гражданство Великобритании, часто затмевает образ британского университетского преподавателя и его младшей дочери Надежды. Последняя проходит через тяжелый процесс (ре-)конструкиии собственной идентичности, пытаясь защитить отиа от второго брака. Будучи гражданкой Великобритании с активной сочиальной позищией, Надежда не только является носителем британских иенностей (хотя она родилась в семье украинских эмигрантов), но как профессор университета успешно транслирует их среди своих студентов до момента, пока в ее жизнь не вторгается «чужой». Реконструкиия идентичности проходит как сложный процесс изучения истории семьи, обращения к собственным национальным истокам, их примирения/согласования с английским укладом. Роль университета и образования оказывается решающей в этом процессе.
\end{abstract}

Ключевые слова: академический роман (Professorroman), иммигрантская литература, университет, идентичность, другой.

Научная специальность: 10.00 .00 - филологические науки. 